\title{
Middle Eastern Belongings
}

Diane King, ed.

New York: Routledge, 2010. 165 pages.

Diane King captures the sentiment undergirding this book by quoting Virginia Dominguez and "returning to "bonds of affection for people or places" (p. 10) in the conclusion of her introduction. She sums up the book's chapters as "hav[ing] in common attention to various ways of belonging in (and, in the case of the European headscarf debates, adjacent to and with reference to) the Middle East. All treat Middle Eastern collectives as sites of what Herzfeld (2005: 6) calls the 'cultural intimacy' of nationalism, in which particular nationalisms are composed of 'the details of everyday life - symbolism, commensality, family and friendship"” (p. 1). Each chapter shows how "belonging" is contested and destabilized in and by imagined communities and fragile states. By addressing questions of violence, moreover, each article highlights "both belonging's messiness and its joys" (p. 10).

King's edited volume ties together six articles and an introduction, all of which previously appeared in Identities, a peer-reviewed cultural anthropology journal published by Routledge. With the exception of the fifth article, which appeared in a separate volume, the articles were published as a special edition, also entitled "Middle Eastern Belongings."

The first chapter by Sarah Persinger, "On the Margins: Women, National Boundaries and Conflict in Saddam's Iraq," historicizes and contextualizes a wave of state-sponsored honor killings of Iraqi women just 
prior to 2003. She explains that Iraqi women were encouraged to work in the 1970s-80s to help first with the growing economy and then with the Iran-Iraq war effort. In the 1990s, however, they were increasingly pushed out of the work force as the economy plummeted, unemployment rose, and conservatism spread. By the late 1990s, Iraqi women increasingly resorted to prostitution. Saddam Hussein, who saw himself as the father of the nation, saw this as a breach of honor to be righted through (honor) killing (suspected) Iraqi women. It is a deadly example of how women represent a country's honor.

In the second chapter, "Leaving Mother-Land: The Anti-Feminine in Fida' $i$ Narratives," Samar Kanafani discusses the construction of an exile Palestinian "nationalism" in Palestinian refugee camps in Lebanon through the narratives of fidayeen, voluntary militia fighters in the 1950s and 1960s. Kanafani demonstrates how the fidayeen constructed Palestinian nationalism overlaid with "hegemonic masculinity" at a time when exiled Palestinians felt politically impotent and emasculated. The third chapter, Diane King's "The Personal is Patrilineal: Namus as Sovereignty," approaches the classical problem of honor killings through a new theoretical paradigm. She proposes that we think about the hymen as the border of the patrilineage, which renders control over who has access to women into a question of patrilineal sovereignty.

The fourth chapter, "Land of Symbols: Cactus, Poppies, Orange and Olive Trees in Palestine," Nasser Abufarha demonstrates not only the significance of the idea of "rootedness" for Palestinian nationalism, but also shows how different plants have symbolized it at different time periods. The fifth chapter, "Naturalizing, Neutralising Women's Bodies: 'The Headscarf Affair' and the Politics of Representation" by Gabriele vom Bruck, offers new insights on "the headscarf affair" in Western Europe by comparing German and French court cases. In the last chapter, "When Belonging Inspires - Death, Hope, Distance," Virginia Dominguez reviews six works of anthropological scholarship on belonging, Palestinian and Jewish identity, and violence. She provides the reader with analytical closure by refocusing on the question: "What does belonging inspire?"

Middle Eastern Belongings makes important ethnographic contributions to current debates on "belonging." As King notes, the book "could be identified with a growing genre of work on belonging" (p. 1). It could be useful to upper-level undergraduate or graduate seminaries on nationalism, ethnicity, anthropology of the Middle East, and even popular Islam. While each article holds its ground theoretically and empirically, more in-depth theoretical 
engagement with some of the "classics" on belonging and personal connectedness (e.g., Anderson 1983; Joseph 1993; Turner 1977) or further examinations of pain and violence, which were present but left untheorized in most of the chapters, would have been helpful.

In addition, a more thematic reorganization of the chapters would have contributed to the book's coherence. As it stands, chapters 1 and 3 with violence against women in Iraq, while chapters 2 and 4 deal with Palestine. For undergraduate or non-specialist readers, chapter 4 could have provided a helpful background understanding for the specific historical events assumed in chapter two. The last two chapters, on the head-scarf debate in western Europe and a literature review, seem less out of place than somewhat unconnected. Though it would have been helpful if she had also addressed the chapters of the book at hand, nonetheless, Dominguez's review essay provides the reader with analytical closure.

The book's main contribution lies in its approach: the theme of violence is juxtaposed with the question of gender without the assumption of a feminist paradigm. In this sense, it follows Saba Mahmood's call for anthropologists of the Middle East and scholars of contemporary Islam to look at how Muslim women (and men) inhabit norms, rather than trying to look for the ways in which they overturn norms. Moreover, chapter 4 ventures beyond issues of gender by discussing plants as metaphors for belonging.

The book addresses "Islamic thought" only contextually. This is somewhat ironic, as all of the chapters describe issues or phenomena explicitly situated among Muslims (albeit, at times "secular Muslims"). Yet, it is also refreshing to read about the joys and pains of belonging in the Middle East without these being reduced to links between Islam and violence.

Edith Szanto (edith.szanto@utoronto.ca)

Ph.D. Candidate, Centre and Department for the Study of Religion University of Toronto, Canada 